\title{
Operation Cost Analysis of Typical Power Plant Waste Incineration
}

\author{
Xiaoning Ye ${ }^{1}$, Xuejiao Lei ${ }^{1}$, Caixia Wang ${ }^{1}$, Qionghui $\mathrm{Li}^{1}$, Wei Yuan ${ }^{1}$ and Ziqian $\mathrm{Li}^{1}$ \\ ${ }^{1}$ State Grid Energy Research Institute Co. LTD Beijing, China
}

\begin{abstract}
In recent years, as the main way to deal with Municipal Solid Waste (MSW), municipal solid waste incineration power generation possesses the dual positive attributes of environmental protection and energy production. In addition to effectively solving the current environmental problems of "cities besieged by garbage", it is possible to become an important supplement of urban energy and an inevitable requirement for economic and social development. Some suggestions are put forward based on the calculation results of actual investment and operating costs of waste incineration power plants. The research results are of great reference value for timely understanding of the status quo of waste incineration power plants, formulating policies and guiding the investment and operation management of power plants.
\end{abstract}

\section{Introduction}

With the rapid development of the economy and the acceleration of urbanization in China, the amount of urban garbage in China has been increasing dramatically, and the problem of waste disposal has become more and more prominent[1-3]. At present, about two-thirds of the cities in China are surrounded by garbage, and onefourth of them do not have any space for refuse landfill, which further exacerbates the "cities besieged by garbage" problem[4]. The cumulative stockpile of municipal solid waste in China has surpassed 7 billion tons, which now occupies a total land area larger than $800,000 \mathrm{mu}$ (about 533 square kilometers), growing at an annual rate of $8 \%-10 \%$. It is estimated that the municipal solid waste production in China will reach 323 million tons by 2020 . The problem of waste disposal has become a major factor restricting the sustainable development of China's economy and society[5-7]. Therefore, waste incineration power generation has become one of the important ways to solve the problem of "cities besieged by garbage" because of its advantages of harmlessness, resource utilization and reduction.

In recent years, with clearer and more definite policies and the increased support of government, waste incineration power plants in China have developed rapidly. However, due to the large scale of construction and investment of waste incineration power plants and high operating costs, a significant requirement is imposed on the economic strength of enterprises investing and operating waste incineration power plants, as well as the level of economic development in the region[ $[8,9]$. As a consequence, it is very difficult for the current market to provide a full and reasonable competitive environment for such projects under the influence of local protectionism and the public welfare characteristics of the industry itself. There are two extreme phenomena which exist in the market. For one thing, the waste incineration power plants which have already been put into operation have very limited profitability and face difficulties in their operations. Therefore, they hope that the government will increase subsidies. For another thing, the unit price for waste disposal keeps decreasing, and some bidding enterprises have won bids at ultra-low prices[10-12]. Therefore, carrying out in-depth analysis and timely grasping of the cost composition and cost status of waste incineration power plants are of great significance for laying down relevant policies, regulations and management measures for waste incineration power generation as well as guiding the healthy and stable development of the waste incineration power generation industry.

\section{Cost Analysis Method for Waste Incineration Power Generation}

\subsection{Cost Composition of Waste Incineration Power Generation}

Based on the whole life cycle of waste-to-power, the cost range and nature of waste power generation are defined. The constituent elements of total cost are determined and broken down by defining the specific components of investment cost and operating costs.

\subsubsection{Investment Cost and Composition}

The investment costs of waste incineration power generation projects mainly include equipment investment costs, including incinerators, fans, flue gas purification systems, waste heat boilers, incinerator

\footnotetext{
* Corresponding author: yexiaoning@sgeri.sgcc.com.cn
} 
supporting facilities and accessories, steam turbine units, generator units, electrical systems, water treatment system and thermal control systems. In addition, there is the cost of civil engineering and land costs. Investment costs in the landfill leachate treatment system can also be divided into building construction costs and machinery and equipment costs.

\subsubsection{Operating Costs and Composition}

The operating costs of waste incineration power generation projects are similar to those of conventional power plants. They mainly include labor costs, power costs, costs of chemicals and disposal of waste water, exhaust gas and waste residue, maintenance costs and production safety expenditures, as well as depreciation costs, taxes and surcharges, management costs and financial costs.

\subsection{Cost Allocation Model of Waste Incineration Power Generation}

According to the composition of the total cost of the project life cycle, which includes investment costs and operating costs, the common formula of the cost allocation matrix model is as follows:

$$
Y *\left(D_{i}+D_{k}\right)+E_{i}=\mu^{*} D_{w}
$$

In which, $Y$ and $\mu$ are the adjustment coefficients of cost variation; $D_{i}$ is the investment cost matrix; $D_{k}$ is the operation cost matrix; $E_{i}$ is the adjusted value of cash inand out-flow; $D_{w}$ is the total cost of the project life cycle.

\subsection{Levelized Cost of Energy (LCOE) Model}

Levelized Cost of Energy (LCOE) refers to the cost of electricity generation per $\mathrm{kWh}$ of a power generation project during the construction and operation cycle. It is a widely accepted and transparent method for calculating the generating cost, and its calculation formula is as follows:

$$
L C O E=\left(\sum_{n=1}^{N} \frac{\text { APPEX }_{n}+O P E X_{n}+T A X_{n}}{(1+r)^{n}}\right) /\left(\sum_{n=1}^{N} \frac{\left(C \times H \times\left(1-O_{N}\right)\right)_{n}}{(1+r)^{n}}\right)
$$

CAPEXn: annual value of initial investment cost, including capital, loans and depreciation; OPEXn: annual value of operation and maintenance cost, including fuel costs, operation and maintenance costs, insurance costs, and labor costs; TAXn: annual tax amount payable by the power plant, including VAT, income tax, education surcharge, urban maintenance and construction tax and land use tax; C: installed capacity; $\mathrm{H}$ : annual utilization hours; ON: rate of house power; N: operation lifespan of power plant; $\mathrm{n}$ : discount rate.

\subsection{Sensitivity Analysis}

Sensitivity analysis refers to a kind of uncertain analysis technique used to study the degree of influence of certain changes of relevant factors on one or a group of key indicators from the perspective of quantitative analysis. The essence is to explain the rule of key indicators affected by the changes of related variables by means of changing the values of these factors one by one.

The calculation method of sensitivity analysis is as follows:

$$
\mathrm{E}=\triangle \mathrm{A} / \triangle \mathrm{F}
$$

Criterion: $\mathrm{E}>0$, indicating that the evaluation indicator changes in the same direction as uncertain factors; $\mathrm{E}<0$ indicates it is going in the opposite direction. The greater $|\mathrm{E}|$ value indicates a higher sensitivity coefficient, and the higher sensitivity of the project benefit to such uncertain factors.

Note: The calculation result of the sensitivity coefficient may vary depending on the rate of change of uncertain factors. However, its value is not the purpose of calculating this indicator. What is important is the relative value of the sensitivity coefficient of the uncertain factor, so as to understand the relative degree of influence of such an uncertain factor, thus selecting the uncertain factor with greater sensitivity.

\section{Cost Analysis for Waste Incineration Power Plant}

\subsection{General Situation of Waste Incineration Power Plant}

A waste incineration power plant with total investment of nearly 3.4 billion yuan is expected to dispose of 3,000 tons of waste per day and 1 million tons of waste per year. Each incineration line has an annual operation time of 8,000 hours and an annual generation capacity of 350 million $\mathrm{kWh}$, including 240 million $\mathrm{kWh}$ of on-grid electricity. The plant disposes of 1,400 tons of crude waste per day, compost residues of 800 tons per day and stale refuse oversized residue of 900 tons per day. Based on the calorific value of the above mentioned waste, the designed lower calorific value of incinerated garbage is $7,530 \mathrm{KJ} / \mathrm{kg}(1,800 \mathrm{kcal} / \mathrm{kg})$, and the designed range of lower calorific value of incinerated garbage is 5,850$9,200 \mathrm{KJ} / \mathrm{kg}(1,400-2,200 \mathrm{kcal} / \mathrm{kg})$.

The incineration line is designed to employ four $750 \mathrm{t} / \mathrm{d}$ mechanical grate-type domestic waste incinerators and four sets of 30MW pumping condensing turbogenerator units. In addition to the electricity supplied for plants in the park, the rest of the generated electricity is transmitted to the power grid for sale. According to the surrounding load demand, this project can also provide some external heat energy.

\subsection{Key Parameters}

\subsubsection{Scale of waste disposal}

Daily household waste disposal capacity of 3,000 tons, annual household waste disposal capacity $100 * 104$ tons; The plant disposes of crude waste at a rate of 1,400 tons per day, compost residue at a rate of 800 tons per day and stale refuse oversized residue at a rate of 900 tons per day. 


\subsubsection{Life cycle and production plan}

The life cycle of the project is 25 years, including a construction period of 2 years plus 7 months and a trial operation period of 6 months.

\subsubsection{Taxation}

VAT on electricity sales is levied at $17 \%$; sales tax and surcharge: urban maintenance and construction tax and education surcharges shall be levied at $7 \%$ and $3 \%$ of VAT. According to relevant national policies, VAT on electricity sales of this project will be immediately refundable. Income tax is charged at $25 \%$ of taxable profits.

\subsubsection{Operating Cost Calculation}

Operating costs includes labor costs, power costs, costs of chemicals and disposal of waste water, exhaust gas and waste residue, depreciation costs, maintenance costs, taxes and surcharges, management costs and financial costs.

\subsection{Cost Calculation and Analysis}

For the LCOE model, in combination with the financial evaluation method of the construction project, and using the Internal Rate Of Return (IRR) as the main evaluation indicator of project financial analysis, the key cost indicator of the power plant is calculated, including the annual average power generation cost, the annual average operation cost, the annual average unit power generation cost and the annual average unit operation cost.

The IRR on industrial capital for waste incineration power generation projects generally falls between $7 \%$ and $9 \%$. Considering the current low interest rate of bank loans, industry competition intensifies. An IRR of $8 \%$ on capital is selected for this calculation. The operating cost data calculated with this model serves as the operating cost of the waste incineration power plant.

Based on the above conditions, the calculation results are as follows:

(1) The annual average power generation cost of a waste incineration power plant is 355.46 million yuan, and the amount of plant waste is 1 million tons. Therefore, the unit power generation cost is 355 yuan/ton.

(2) The annual average operation cost is 242.14 million yuan, and the unit operating cost is 242 yuan/ton.

(3) The annual average revenue of waste power generation is 158.53 million yuan and the unit revenue of waste power generation is 158 yuan/ton, so the cost coverage rate of power generation revenue is $45 \%$.

(4) Break-even subsidy price: When the government subsidy for the waste disposal service fee reaches 355$158=197$ yuan/ton, the profit and loss balance of the project can be achieved. In view of the payback period of accounts receivable, the estimated break-even service fee for waste disposal should be appropriately increased.
The subsidy for the waste disposal fee granted to waste incineration power plant is 292.5 yuan/ton. The cost profit margin is calculated to be higher than $10 \%$, which indicates a good level of profit.

\subsection{Sensitivity Analysis}

Sensitivity analysis is carried out with the waste disposal fee set as the target value and IRR and fixed asset investment as uncertain factors, through which the change scope of the waste disposal service fee can be determined in the cases of IRR being increased by $1 \%$ and $2 \%$, and decreased by $1 \%$ and $2 \%$, and fixed asset investment being increased by $5 \%$ and $10 \%$ and decreased by $5 \%$ and $10 \%$, respectively.

\subsubsection{The Impact of Capital IRR on Waste Disposal Service Fees}

Assumed that IRR on Capital increases by $1 \%$ and $2 \%$, and decreases by $1 \%$ and $2 \%$, respectively, the unit price of the waste disposal service fee is shown in the table below with other conditions unchanged.

Table 1 Sensitivity Analysis of the Unit Price of the Waste Disposal Fee to IRR on Capital

\begin{tabular}{ccc}
\hline Capital IRR & $\begin{array}{c}\text { Unit Price of } \\
\text { Waste Disposal } \\
\text { Service Fee } \\
\text { (yuan/ton) }\end{array}$ & $\begin{array}{c}\text { Amount of } \\
\text { Variation (\%) }\end{array}$ \\
\hline $6 \%$ & 140 & $-30 \%$ \\
$7 \%$ & 170 & $-15 \%$ \\
$8 \%$ & 200 & $0 \%$ \\
$9 \%$ & 230 & $15 \%$ \\
$10 \%$ & 260 & $30 \%$ \\
\hline
\end{tabular}

As indicated in the table above, when the IRR on capital is increased by $1 \%$ and $2 \%$, the unit price of waste disposal service is increased by $15 \%$ and $30 \%$, accordingly. When the IRR on capital is decreased by $1 \%$ and $2 \%$, the unit price of the waste disposal service fee is decreased by $15 \%$ and $30 \%$, respectively. Therefore, the IRR on capital is a cost-sensitive factor for waste incineration power plants.

\subsubsection{The Impact of Initial Investment Cost on Waste Disposal Service Fees}

Assuming that initial investment cost increases by 5\% and $10 \%$, the unit price of the waste disposal service fee is shown in the table below, with other conditions unchanged.

Table 2 Sensitivity Analysis of Unit Price of Waste Disposal Fee to Initial Investment Cost

\begin{tabular}{ccc}
\hline $\begin{array}{c}\text { Initial Investment } \\
\text { Cost (yuan x }\end{array}$ & Unit Price of & Amount of \\
Waste Disposal & Variation (\%) \\
\hline
\end{tabular}




\begin{tabular}{ccc}
\hline 10,000$)$ & $\begin{array}{c}\text { Service Fee } \\
\text { (yuan/ton) }\end{array}$ & \\
\hline 163,203 & 164 & $-18 \%$ \\
181,115 & 182 & $-9 \%$ \\
199,028 & 200 & $0 \%$ \\
218,930 & 220 & $10 \%$ \\
236,843 & 238 & $19 \%$ \\
\hline
\end{tabular}

As indicated in the table above, when the initial investment cost is increased by $5 \%$ and $10 \%$, the unit price of the waste disposal service increases by $10 \%$ and $19 \%$, respectively; when the initial investment cost is decreased by $5 \%$ and $10 \%$, the unit price of waste disposal service decreases by $9 \%$ and $18 \%$, respectively. Therefore, initial investment is a cost-sensitive factor for the waste incineration power plant.

The sensitivity analysis of IRR and initial investment cost is as follows:

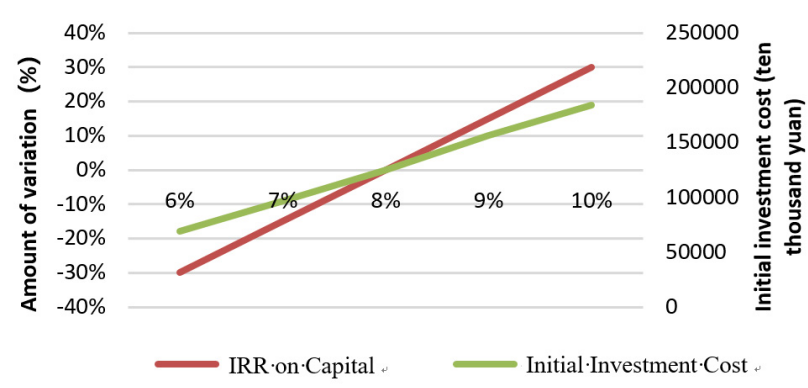

Fig.1 Sensitivity Analysis Diagram

\section{Conclusions}

(1) Waste incineration power plants cannot achieve profit-loss balance without government subsidies in the waste disposal fee. In the case calculated above, the subsidy per ton should be 100-300 yuan, in consideration of reaching the requirements of industry profitability.

(2) The current subsidy for waste disposal fees to waste incineration power plants is 292.5 yuan/ton, and the break-even subsidy price is 197 yuan/ton. Considering the payback period of accounts receivable, the subsidy for the power plant's break-even waste disposal fee needs be increased slightly. As long as the subsidy standard for the power plant's waste disposal fee is higher than that of the break-even subsidy standard, profitability can be achieved.

(3) Therefore, the IRR on capital and initial investment cost are cost-sensitive factors for waste incineration power plants. When the IRR on capital increases by $1 \%$ and $2 \%$, the unit price of waste disposal services is increased by $15 \%$ and $30 \%$, accordingly; when the IRR on capital is decreased by $1 \%$ and $2 \%$, the unit price of waste disposal service is decreased by $15 \%$ and 30\% respectively. When the initial investment cost is increased by $5 \%$ and $10 \%$, the unit price of waste disposal service increases by $10 \%$ and $19 \%$, respectively; when the initial investment cost is decreased by $5 \%$ and
$10 \%$, the unit price of waste disposal service decreases by $9 \%$ and $18 \%$, respectively.

\section{Acknowledgements}

This work is supported by State Grid Corporation Science and Technology Project (Clean energy consumption potential analysis and optimization technology considering the flexibility of power transmission planning, SGGSKY00FJJS1800025). The authors thanks State Grid Gansu Electric Power Supply Company for funding the project.

\section{References}

1. KPMG. Cost Estimation and Analysis Report of Waste Incineration Power Generation BOT Project, 2015.

2. J.W. Liu, T.Z. Lei, S.H. Yang, et al. Discussion on the status quo and development trend of waste incineration power generation in China [J]. Sinoforeign Energy, 2012 (6): 29-33.

3. C. Feng. Development Strategy of Waste Incineration Power Plant[D]. Nanjing University 2013.

4. C.S. Shi. Comprehensive Benefit Analysis of Pudong Waste Incineration Power Plant Project[D]. Fudan University 2013.

5. H.B. Chen. Research on investment analysis of waste power plants[D]. Shanghai Jiaotong University 2007.

6. H.X. Zhang, A.M. Li, J.W. Yang. Application prospects and existing problems of waste incineration power generation technology in China[J]. Chemical Industry and Engineering Progress, 2010(29): 91-95.

7. Y.D. Chang. Analysis of current status and social benefits of waste-to-energy industry-taking Zhangjiakou City as an example[J]. Market Research, 2015(7): 89-92.

8. W.W. Zhang. Status and prospects of waste-toenergy generation[J]. Shandong Industrial Technology, 2015(10): 162-165.

9. W. Zhong, G.F. Zhu. Overview of Waste-to-Energy Technology $[\mathrm{J}]$. China Resources Comprehensive Utilization, 2006(10): 27-31.

10. W. Gu. Research on the classification and treatment of urban waste in China[D]. Nanjing University of Science and Technology 2015.

11. N. Zhang. Analysis of investment prospects of China's waste incineration power generation industry[D]. North China Electric Power University 2012.

12. J.H. Han. Discussion on the status quo and trend of waste-to-energy generation[J]. Shandong Industrial Technology, 2016(1): 171-174. 